\title{
A aprendizagem organizacional e suas bases econômicas
}

\section{Palauras-chave}

aprendizagem organizacional, economia baseada em conhecimento e competências organizacionais.

Classificação JEL B5, O3, I25

\section{Keywords}

organizational learning, knowledge-based economy, organizational competencies.

JEL Classification $B 5, O 3, I 25$

\section{Resumo}

Este artigo objetiva apresentar os nexos teóricos que, a partir da Economia, justifiquem a importância do estudo do fenômeno da aprendizagem organizacional, mais tipicamente abordado na Administração. Em primeiro lugar, são discutidas as características das economias baseadas em conhecimento e suas exigências em termos de aprendizado e desenvolvimento de competências organizacionais. Em segundo lugar, a partir das limitaçôes dos pressupostos neoclássicos em relação à organização, é abordada a noção de estratégia. A seguir, são apresentadas origens do conceito de competências na teoria da firma baseada em recursos e seus desdobramentos para os estudos sobre estratégia e competências. No próximo passo, são destacados elementos conceituais do campo da aprendizagem organizacional. Por fim, identificam-se ligaçóes existentes entre a vida organizacional e a abordagem econômica, nos aspectos que relacionam o conhecimento e a aprendizagem organizacionais ao desenvolvimento econômico
Wilson Aparecido Costa de Amorim Departamento de Administração da FEA USP

André Luiz Fischer

Departamento de Administração da FEA USP

Abstract

This paper intends to show the theoretical links that justify why it is important to study, from an Economics point of view, the phenomenon of organizational learning - which is traditionally studied in Business Management. The first step shows the characteristics of Knowledge-Based Economies and their needs regarding organizational learning and the development of competencies. The second step criticizes the neoclassical assumptions about organizations and stresses the importance of the notion of strategy. The third step discusses the origins of the concept of competencies, in the Resource-Based View of the Firm, and its influence on organizational competencies and strategy. The fourth step points out the concepts of the field of organizational learning. Finally, the paper shows the links between organizational life and the economic approach, mainly as they relate the concepts of knowledge, organizational learning and economic development. 


\section{1_Introdução}

A luta das organizaçóes pela liderança, ou simplesmente pela sobrevivência, em um mercado que se move com rapidez, liga-se indissoluvelmente à sua capacidade de adaptação e inovação. A interpretação correta dos sinais do mercado ou, de maneira mais ambiciosa, a criaçáo de referências inovadoras para o mercado são atividades dependentes da capacidade de compreensão e elaboração da organização e seus integrantes. Em um mundo de informação cada vez mais abundante, conhecer e aprender são atividades ou habilidades indispensáveis para toda e qualquer organização, seja pública ou privada, seja empresarial ou sindical.

Quando o conhecimento e a aprendizagem tornam-se assuntos da Economia e Administração, novas polêmicas somam-se às já existentes em outros campos como Filosofia, Psicologia, Pedagogia e Tecnologia. A Economia e a Administração têm grande exigência quanto à operacionalização de seus conceitos. $\mathrm{Na}$ Economia, as questóes em torno do conhecimento e da aprendizagem demandam posicionamento do Estado e suas políticas públicas de educação, formação profissional e também de apoio à ciência. $\mathrm{Na}$ Administração, o ato de conhecer e aprender nas organizaçóes deve conectar-se aos seus objetivos, ou seja, tornar-se parte da gestão. Por esse motivo, detectar os melhores caminhos para o desenvolvimento de processos de disseminação e criaçáo de conhecimento e aprendizagem encontra-se entre as prioridades das preocupaçóes das organizaçóes.

Este trabalho objetiva estabelecer os nexos teóricos que, com base na Economia, justifiquem a importância do estudo do fenômeno da aprendizagem organizacional, mais tipicamente abordado no campo da Administraçáo. Além desta introdução, este artigo conta com as seguintes partes: inicialmente sáo discutidas as características das economias baseadas em conhecimento e suas exigências em termos de aprendizado e desenvolvimento de competências organizacionais. A seguir, tendo em vista as limitaçóes dos pressupostos neoclássicos em relação à organização, é abordada a importância da noção de estratégia. No tópico seguinte, são apresentadas algumas das origens do conceito de competências na teoria da firma baseada em recursos e seus desdobramentos para os estudos sobre estratégia e competências. No próximo passo, são destacados os elementos conceituais referentes ao campo da aprendizagem organizacional. Finalmente, em um caminho de volta, identificam-se ligaçóes existentes entre a vida organizacional e a abordagem econômica, principalmente 
nos aspectos que relacionam o conhecimento e a aprendizagem organizacionais ao desenvolvimento econômico.

\section{2_A Economia Baseada em Conhecimento}

Nesta parte são apresentados sinteticamente aspectos do conhecimento e aprendizagem relacionados à Economia. Para isso, são destacados os autores neoschumpeterianos (que formulam o conceito de Economia Baseada em Conhecimento) e autores dedicados à Teoria da Firma Baseada em Recursos. A intenção é destacar os fundamentos econômicos da atual valorização do conhecimento e da aprendizagem nas organizaçóes contemporâneas e, assim, demonstrar as ligaçóes entre a Economia e o conceito de competências e suas implicações para as organizaçóes.

\section{1_Schumpeter: inovação e desenvolvimento econômico}

As principais obras do economista austríaco Joseph Alois Schumpeter (18831950) refletem sua preocupação com as graves crises econômicas e políticas de seu tempo, como as duas grandes guerras e o advento da revolução comunista. Autor de difícil enquadramento nas escolas econômicas, ele analisa crítica e criativamente ideias ideologicamente distantes entre si - como as de Marx e Marshall - nos principais assuntos da Economia, entre eles, o processo de desenvolvimento econômico.

Para Schumpeter, o processo de desenvolvimento econômico é composto de ciclos econômicos que, por sua vez, se relacionam às ondas de inovação. Segundo ele, o impulso fundamental para a dinâmica econômica era dado pelo novo, que na sua chegada realizava a "destruição criadora" - um dos seus mais importantes conceitos - dos elementos baseados nas velhas formas da produção. $\mathrm{O}$ surgimento de outros bens de consumo, outros métodos de produção ou transporte, outros mercados e outras formas de organizaçáo industrial...

"'revoluciona' a estrutura econômica a partir de dentro, incessantemente destruindo a velha, incessantemente criando a nova" (Schumpeter, 1984, p. 113).

Desta forma, a presença bem-sucedida do novo na economia destruiria as oportunidades de sobrevivência das estruturas velhas através da concorrência capitalista. O autor assinala que a concorrência capitalista não acontece conforme a visão tradicional em que o preço tem função dominante, e os padróes de produção não variam. Em sua opinião, a principal concorrência ocorre na forma 
da venda de novas mercadorias, na utilização de novas tecnologias, novas fontes de oferta e mesmo de novas formas de organização da produção. Essa concorrência, baseada na inovação, visa ao lucro e, indo além, seria capaz de alterar os próprios fundamentos das empresas. Nela, o empresário, mesmo como monopolista, sente-se concorrendo pela simples ameaça de que outros empresários venham disputar seu mercado. Por causa disso, busca a inovação (Schumpeter, 1984, p. 114-115). No balanço entre custos e benefícios para a economia como um todo, as perdas provocadas nos setores perdedores nessa disputa seriam mais que compensadas pelos benefícios trazidos pelas inovaçóes, ainda que sob a responsabilidade de empresas monopolistas.

A figura do empresário inovador desempenha papel importante nos movimentos de inovação na economia. Schumpeter critica as definiçóes mais tradicionais da figura do empresário ([uma delas] "[...] bem conhecida, que remonta a J. B. Say': a função do empresário é combinar os fatores produtivos, reuni-los", [ou conforme] "[...] a versão marshalliana de empresário, que trata a função empresarial simplesmente como 'administração'”) e entende que ele deve ser um líder que assume os riscos inerentes da inovação, conduz os meios de produção em direção aos novos canais e, ao fim, lidera a própria concorrência que seguirá seus passos pelo caminho aberto (Schumpeter, 1982, p. $54,55,63)$.

É curioso que, a despeito de perceber a importância dos processos de inovação no âmbito econômico, Schumpeter fosse bastante pessimista quanto ao futuro do capitalismo. Para ele, o declínio do capitalismo ocorreria em função de pelo menos três fatores: a substituição gradual do empreendedor pela burocracia gerencial das grandes empresas, a resistência dos intelectuais relativamente ao sistema capitalista e também o crescimento da intervenção estatal na economia. A combinação desses elementos resultaria na perda do ímpeto pela acumulação causada pela saída de cena, ou mesmo pela redução do espaço de atuação do empreendedor inovador, elemento-chave no capitalismo. Sua previsão era que desse declínio adviria o socialismo (Fusfeld, 2001, p. 224-225).

O tempo mostrou que Schumpeter equivocou-se em sua previsão. As décadas seguintes ao lançamento de seu último livro foram marcadas por expressivo crescimento econômico mundial, e, já no final da década de 80 , aconteceria a própria derrocada dos regimes socialistas pelo mundo. De qualquer modo, a sua abordagem para a relação entre inovação
${ }^{1}$ Jean Baptiste Say (1767-

1832), economista francês que, com base na leitura de Adam Smith e David Ricardo, formulou uma lei econômica segundo a qual toda oferta gera a própria demanda (decorrendo daí uma situação de pleno emprego para a economia). Essa lei econômica é um dos fundamentos primeiros da teoria econômica neoclássica (Miglioli, 1985). 
e desenvolvimento mostrou-se bastante pertinente para a compreensão dos fenômenos econômicos nas últimas décadas.

\section{2_Economia Baseada em Conhecimento: um onceito neoschumpeteriano}

A importância dada por Schumpeter à inovação dentro do processo de desenvolvimento econômico abriu caminho para interessantes abordagens relativamente à aprendizagem e ao conhecimento na Economia. Isso porque a noção de inovação na economia traz implícitas a criação e a aquisição de conhecimento por meio das pesquisas necessárias para a produção de novos produtos e processos, e - inseparável desses dois fenômenos - a necessidade de aprendizagem. Em outras palavras, conhecer e aprender situam-se no centro do processo produtivo.

A expressão "Economia Baseada em Conhecimento" (EBC) tem como precursor um economista heterodoxo entre os autores neoclássicos: Machlup (1962). Esse autor desenvolveu trabalhos teóricos e de pesquisa sobre a economia do conhecimento e informação já no início da década de 60 e concluiu pela existência de grandes transformaçóes nas economias industrializadas, entre elas o aumento da participação dos setores intensivos em conhecimento (Lenhari; Quadros, 2002).
Posteriormente, Foray e Lundvall estudam a Economia Baseada em Conhecimento e assinalam pelo menos dois fatos importantes que dificultam teoricamente a aplicação dos princípios econômicos fundamentais tradicionais à generalização e à produção de conhecimento:

a_ existem grandes mudanças no modo de produção e distribuição de conhecimento (nova dinâmica entre conhecimento tácito e codificado, aumento de importância das redes de trabalho, aceleração do processo de aprendizado) que precisam ser repensados em termos dos princípios econômicos;

b_ há importantes assuntos políticos - globalização, subdesenvolvimento, crescimento econômico sustentável, questóes ambientais - que precisam ser interpretadas sob a luz da Economia (com foco no conhecimento e aprendizado) (Foray; Lundvall, 1996, p. 12).

Desde sempre, a capacidade do homem para aprender novas habilidades e transmiti-las às demais geraçóes ocupa funçâoo relevante na atividade humana. Entretanto, relativamente às etapas históricas 
anteriores, a atual é caracterizada por mudanças importantes na relação entre conhecimento e desenvolvimento (Foray; Lundvall, 1996, p. 13).

A corrente neoschumpeteriana trata das grandes mudanças do capitalismo e estuda a divisão do trabalho que existe e é organizada nos chamados sistemas nacionais de inovação (Paula et al., 2000, p. 421). Tais autores (como Foray e Lundvall) estão envolvidos com a formulação de uma nova teoria do crescimento econômico que compreende os papéis do conhecimento e da tecnologia enquanto geradores de produtividade e desenvolvimento. Elementos como investimentos em pesquisa e desenvolvimento, educação e treinamento, e novas formas de gerenciamento tornam-se importantes do ponto de vista dessa análise.

Institucionalmente, os estudos e as pesquisas desenvolvidos pelos neoschumpeterianos influenciam as discussóes dos países da Organização para a Cooperaçáo e Desenvolvimento Econômico - OCDE (OECD, 1996). Os estudos dos autores neoschumpeterianos oferecem insumos para a elaboração de instrumentos e políticas adequadas à situação dos países da OCDE, cujos setores intensivos em conhecimento e tecnologia tendem a ser os mais dinâmicos em termos de crescimento. As principais conclusões destes estudos se encontram em documento de 1996 (OECD, 1996).

A seguir, são sumarizados: características, tendências e implicaçóes da $E B C$, seus principais indicadores e também o papel desempenhado pelo sistema científico.

A EBC poderia ser descrita baseando-se pelo menos em três fenômenos. Analisaremos a seguir cada um deles.

\section{a_Nova dinâmica na formação de}

conhecimento tácito e codificado

Esta nova dinâmica seria dada pela intensificação do processo de codificaçáo do conhecimento, ou seja, a sua transformação de conhecimento tácito - fundado na experiência e não sistematizado - em explícito. O documento da OCDE aponta quatro tipos de conhecimento envolvidos nessa dinâmica:

A codificação do conhecimento ocorreria principalmente por meio da transformação do know-how e do know-who em registros sistematizados e de fácil acesso e manuseio, ou seja, em um estágio no qual esses conhecimentos possam constituir informação. As tecnologias de informação permitem crescente codificação do conhecimento e a sua disponibilidade nos bancos de dados. Tais eventos conferem ao conhecimento, uma vez sistematizado e disponível, a característica de commodity, 
Quadro 1_Conhecimentos: tipos e fontes

\begin{tabular}{|c|c|}
\hline Tipo de conhecimento & Fonte \\
\hline $\begin{array}{l}\text { Conhecimento e informaçáo } \\
\text { - Know-what: o conhecimento sobre fatos } \\
\text { (que seria muito próximo da informação) } \\
\text { - Know-why: refere-se ao conhecimento científico } \\
\text { sobre as leis da natureza }\end{array}$ & - livros, aulas ou do acesso a bancos de dados \\
\hline $\begin{array}{l}\text { Conhecimento tácito } \\
\text { - Know-how: habilidade ou capacidade de fazer algo } \\
\text { - Know-who: o conhecimento sobre "quem sabe o quê" } \\
\text { ou "quem sabe fazer o quê" }\end{array}$ & $\begin{array}{l}\text { - tipicamente apreendido nas situaçóes em que o aprendiz } \\
\text { acompanha seu mestre e o reconhece como autoridade } \\
\text { - é apreendido na prática social e às vezes em ambientes } \\
\text { educacionais específicos }\end{array}$ \\
\hline
\end{tabular}
${ }^{2}$ Neste parágrafo, os conceitos de conhecimento e informação são usados, como na fonte, indistintamente como sinônimos.
${ }^{3}$ Moreira e Queiroz (2007, p. 9) apontam que existem cerca de 20 diferentes classificações
é nosso objetivo aprofundar
a discussão em torno dessas
classificações, e, por isso, nossa
referência será a taxonomia de
Knight (1967) que, conforme
os autores, é uma das
utilizadas há mais tempo.

ou seja, uma matéria-prima padronizada e de baixo custo.

A continuidade do processo de codificação por meio da tecnologia move os limites entre os conhecimentos tácito e explícito, extraindo as experiências de pessoas e organizações e colocando-as à disposição de outras. A codificação crescente do conhecimento permite ainda a criação de pontes entre campos e áreas de conhecimento diminuindo sua dispersão.

\section{b_Importância crescente das redes de conhecimento} Segundo a EBC, e de acordo com a lógica schumpeteriana, a Economia tem na inovação uma de suas principais forças, o que evidentemente pressupóe conhecimento. O uso e a difusão da informação tornam-se tão importantes quanto a criaçáo do conhecimento. ${ }^{2}$ Dada a crescente possibilidade de acesso à informação, o surgimento da inovação pode ocorrer tendo por base várias fontes, inclusive de novas capacidades de manufatura e de reconhecimento de necessidades do mercado.

Para Knight, as inovaçóes podem ser classificadas em quatro tipos ${ }^{3}$ : inovaçóes no produto ou no processo (novos produtos ou serviços oferecidos pela organização), inovaçóes no processo de produção (novos elementos nas tarefas 
da organização, seu sistema de informação ou na produçáo física ou operaçóes de serviços), inovaçôes na estrutura organizacional (mudanças nas relaçóes de autoridade, alocaçóes de trabalho, nas formas de remuneração, nas formas de comunicação, etc.) e inovação nas pessoas (mudanças de comportamento ou crenças por meio de educaçáo e treinamento) (Moreira; Queiroz, 2007, p. 9-10).

Em busca da inovação, as empresas que atuam na $\mathrm{EBC}$ procurarão conectar-se com outras para promover um aprendizado interativo, e assim, mediante a constituição de verdadeiras redes, deverão encontrar parceiros com os quais possam obter bens complementares à sua produção. Ao estabelecer essas relaçóes, as empresas poderão dividir os custos e os riscos associados às inovaçóes entre as diversas organizaçóes, acessar os resultados das pesquisas, adquirir componentes tecnológicos importantes de produtos e processos e dividir ativos na manufatura, no marketing e na distribuição.

$\mathrm{Na}$ EBC, o novo não é necessariamente uma sequência fixa e linear de acontecimentos, como determina a visão econômica tradicional do processo de inovaçáo (no qual as descobertas acontecem em fases de desenvolvimento do produto, produção, marketing e finalmente ocorre a venda dos novos produ- tos e serviços). Para inovar, a economia se articula em redes, e estas, conforme suas necessidades, estabelecem uma hierarquia voltada para a aceleraçáo da taxa de mudança e da taxa de aprendizagem. As instituiçóes de pesquisa, as universidades e o próprio governo podem tomar parte dessas redes. Da interação entre esses atores, pode-se constituir um sistema voltado para a inovação.

\section{c_Aceleração dos processos de aprendizado interativo}

A competição impele à inovação. A inovaçáo, dependente do conhecimento, dá margem ao movimento de codificaçáo da informação e do desenvolvimento das competências para uso dessa informação. Dessa forma, a EBC é caracterizada pela necessidade de aprendizado contínuo em que a educaçáo ocupa papel central para o avanço dos indivíduos, das organizações e das sociedades. ${ }^{4}$

Todo esse processo confluiria para a montagem de um Sistema Nacional de Inovação (SNI). O SNI seria composto dos fluxos e das relaçóes existentes entre empresas, indústria, governo e academia no desenvolvimento da ciência e tecnologia e que influenciam empresas e economias. A ilustração 1 traz uma forma de representação de um SNI.

Uma vez percebida sua lógica de funcionamento, a $E B C$ pode ser definida

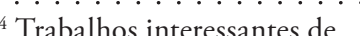
Meister (1999) e Eboli (2004) (esta autora, especialmente para o caso brasileiro) estabelecem a ligação entre as iniciativas das empresas (que necessitam de aprendizado contínuo) e as universidades corporativas como forma de proporcionar educação continuada aos seus funcionários e, eventualmente, parceiros. 


\section{llustração 1_Sistema Nacional de Inovação - hélice tripla ${ }^{5}$}

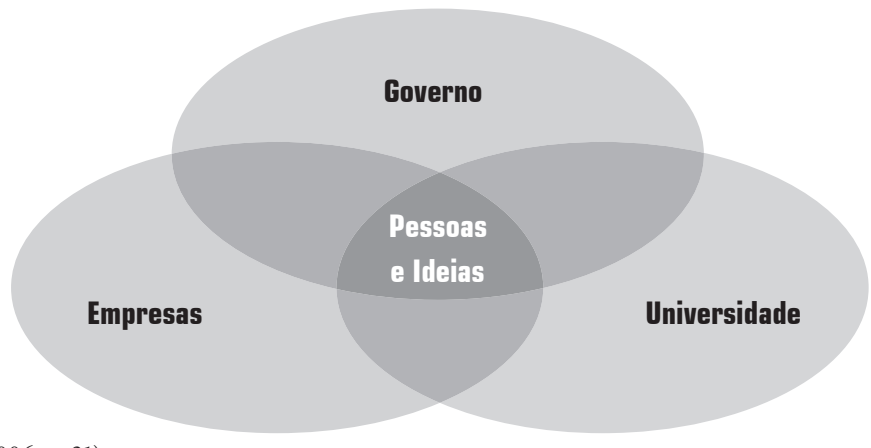

Fonte: Stal et al. (2006, p. 21)

como uma economia baseada diretamente na produção, na distribuição e no uso do conhecimento e da informação. Entre as suas características, estão a preexistência de um sistema nacional de inovaçáo maduro; papel da infraestrutura de conhecimento é importante no sistema de inovação; construção de infraestrutura informacional (como consequência dasTecnologias de Informação e Comunicação - TICs); sofisticação da divisão do

${ }^{5} \mathrm{O}$ modelo recebe este nome porque cada hélice (empresas, governo e universidade) é "[...] uma esfera institucional independente, mas trabalha em cooperação e interdependência com as demais esferas, por meio do fluxo de conhecimento entre elas (STAL et al, 2006, p. 20).
${ }^{6}$ Citando duas das dificuldades, o relatório aponta a inexistência de um sistema de preços de conhecimento que servisse de base para agregaçóes nacionais e, mensuração da adição líquida de conhecimento (conhecimento novo menos conhecimento obsoleto) na economia (OECD, 1996, p. 30-31). trabalho (com participação expressiva da força de trabalho na produção, na difusão e na transmissáo de conhecimentos).

Os trabalhos desenvolvidos no âmbito da OCDE preocupam-se em instrumentalizar as políticas públicas quanto à relação entre conhecimento e desenvolvimento. Com isso, da análise dessa economia chega-se à sua definiçáo, caracterização, avaliação-mensuração e, finalmente, à elaboração de uma abordagem prescritiva.

Todavia, as dificuldades de mensuração econômica dos chamados ativos intangíveis são inúmeras, tanto nas empresas quanto no nível das economias nacionais. Nas economias nacionais, o tradicional sistema de contas nacionais lida prioritariamente com um mundo econômico de bens tangíveis e não permite a compreensão dos fenômenos da economia do conhecimento. ${ }^{6}$ 
Para isso, o relatório da OCDE apresenta uma série de indicadores voltados para a mensuração econômica de insumos, estoques e fluxos de conhecimento, bem como do desempenho de redes e de aprendizado. ${ }^{7}$ Com indicadores disponíveis a respeito do conhecimento, seria possível estabelecer parâmetros de eficiência em termos da capacidade ou poder de uma economia em distribuir conhecimento. A avaliação dos fluxos de conhecimento entre os participantes do sistema nacional de inovaçãoo (universidades, centros de pesquisa, empresas, etc.) ou da distribuiçáo de conhecimento no mercado entre ofertantes e usuários torna-se, então, uma referência para a avaliação do desenvolvimento de um país (OECD, 1996, p. 40).

A abordagem desenvolvida pelos neoschumpeterianos traz um conjunto de conceitos novos (EBC, Economia do Aprendizado e Sistema Nacional de Inovação) são incorporados às discussóes da OCDE. Com base nesses conceitos, a OC$\mathrm{DE}$ chega às proposições práticas de instrumentos à disposição das políticas públicas. A seguir são abordados os desafios conceituais e práticos da EBC.

Paula et al. (2000) analisam o conceito de SNI e destacam que, no polo do trabalho intelectual da economia, existe uma sofisticação da divisão do trabalho por meio da interação que passa a figurar nas redes que compóem o SNI (centros de pesquisa, universidades e áreas de $\mathrm{P} \& \mathrm{D}$ das grandes empresas). Os autores assinalam ainda que a sofisticação da divisão do trabalho é institucionalmente organizada e busca meios para viabilizar a aplicação sistemática da ciência à produção.

Para os neoschumpeterianos, a inovação é a mola propulsora da concorrência. As necessidades de conhecimento e aprendizado daí decorrentes tornam-se dependentes do desenvolvimento da capacidade dos indivíduos, que, por sua vez, têm como seu ponto de partida a educação. Estabelece-se aqui um ponto de contato com o conceito de capital humano desenvolvido por Marshall. ${ }^{8} \mathrm{~A}$ dinâmica da EBC, porém, não se relaciona apenas à educação formal, mas também à necessidade de aprendizado contínuo, dado que a inovação resulta das novas lei-

\begin{tabular}{|c|c|}
\hline${ }^{7}$ O Banco Mundial & comunidade para o trabalho \\
\hline dispóe de um interessante & qualificado, a inovação \\
\hline instrumental voltado para a & científica e tecnológica, a \\
\hline mensuração do conhecimento & liderança, a iniciativa e \\
\hline nos países que permitem & a organização em nível \\
\hline estudos comparativos. Vide & empresarial privado e na vida \\
\hline “Knowledge Assessment & pública (Fonseca, 1992, p. 79). \\
\hline Methodology - KAM” in & Para Marshall, caberia ao \\
\hline $\begin{array}{l}\text { www1.worldbank.org/gdln/ } \\
\text { kam.htm. }\end{array}$ & $\begin{array}{l}\text { Estado, mediante o provimento } \\
\text { da educaçáo universal, garantir }\end{array}$ \\
\hline $\begin{array}{l}{ }^{8} \text { Segundo Marshall, o capital } \\
\text { humano seria definido como } \\
\text { o grau de capacitaçáo da }\end{array}$ & $\begin{array}{l}\text { condiçóes para a oferta } \\
\text { adequada do capital humano } \\
\text { (Marshall, 1985, p. } 91 \text { ). }\end{array}$ \\
\hline
\end{tabular}


turas da realidade permitidas pela ciência e pela tecnologia em geral, em especial aquelas relacionadas à informação.

O lado prescritivo das ideias neoschumpeterianas, por sua vez, indica que a esfera pública também tem por tarefa a elaboração de políticas públicas voltadas para o estímulo às inovaçóes. As prioridades dessas políticas seriam o incentivo à difusão tecnológica, o incremento do capital humano e a promoção da mudança organizacional (OECD, 1996, p. 19). Nesta linha, Lundvall afirma que uma política voltada à inovação deveria contribuir para a capacidade de aprendizagem das empresas, das instituiçóes voltadas para o conhecimento e das pessoas. Em poucas palavras, a aprendizagem deve ser o objetivo em todos os lugares, inclusive nas organizaçóes. Desta forma, alguns dos elementos centrais para a aprendizagem seriam o desenvolvimento de recursos humanos, as novas formas de organização empresarial, a formação de redes, a definição de uma nova função dos serviços intensivos em conhecimentos e das universidades (Lundvall, 2003, p. 117).

Segundo Lundvall, mudança e aprendizado são faces de uma mesma moeda. Competir, aprender, inovar e novamente competir são ações que compõem um processo circular e cumulativo (Lundvall, 2003, p. 117). Nesse processo, a capacidade de sobrevivência de uma organização passa a depender de sua capacidade de adquirir e desenvolver competências - vale dizer, aprender - que, por sua vez, é altamente dependente do desenvolvimento e da apropriaçáo de conhecimento. A organização é levada a uma contínua preparação por melhor gestão, habilidades ou mesmo estruturas organizacionais, que se conformam em novos conhecimentos.

\section{3_Economia, organização e estratégia}

Do ponto de vista teórico, ao lidar com desenvolvimento econômico, inovação e competição, Schumpeter apresentou visão bastante diversa da economia neoclássica. De modo geral, sua visão situou a inovaçấo no centro da questão econômica e traz a necessidade de melhor entendimento das mudanças que acontecem nas organizações quando essas promovem ou incorporam inovaçóes.

Os autores neoschumpeterianos preocupados com o ambiente institucional no qual convivem empresas, governos, universidades e centros de pesquisa - também desenvolveram um conjunto conceitual bastante distante da teoria neoclássica.

A teoria neoclássica compreende a firma ou a empresa como um espaço em que as mudanças ou o aperfeiçoamento 
acontecem de forma incremental, ou seja, ela náo se altera radicalmente no tempo. De maneira geral, na teoria neoclássica, a tecnologia e as preferências são dadas. Além disso, por conta do conhecimento perfeito, as escolhas possíveis ao produtor também são dadas, e a melhor escolha é, pela obviedade, fácil de ser identificada (Nelson, 2006). Para Nelson (2006), a economia neoclássica tende a tomar as organizaçóes como semelhantes, quando na verdade há diferenças entre elas, e tais diferenças são importantes do ponto de vista econômico.

A admissão de que as organizações inovam, promovem rupturas tecnológicas, mudam e evoluem demanda novos pressupostos para o seu funcionamento. Nelson sintetiza em duas obras de Alfred D. Chandler (Strategy and Structure, 1962, e Scope and Scale, 1992) contribuições importantes nessa busca (Nelson, 2006).

$\mathrm{Na}$ primeira obra, Chandler assinala que as organizaçóes adotam uma estratégia e que esta, por sua vez, define as linhas gerais de sua estrutura. Estratégia e estrutura - características mais abrangentes e duradouras de uma organização - orientam sua evoluçáo interna e suas aptidôes essenciais. A estratégia seria

"[...] conjunto de compromissos assumidos por uma empresa para definir e racionalizar seus objetivos $e$ os modos como pretende consegui-los".

A estrutura envolveria

"[...] a forma de organização e de governo da empresa, e de como as decisóes são efetivamente tomadas e levadas adiante, determinando assim o que ela faz de fato, a partir de sua ampla estratégia" (Nelson, 2006).

$\mathrm{Na}$ segunda obra, ainda segundo Nelson, Chandler destaca a importância da relaçáo entre a organizaçáo e seu ambiente, e sua influência nos seus moldes estratégico e estrutural e no desempenho. Com base em Chandler, Nelson afirma que a estratégia empurra a organizaçáo para, quando necessário, mudar sua estrutura e buscar ou reforçar aptidóes essenciais à sua performance - entre elas a de inovação (Nelson, 2006).

Outro autor que questiona a validade dos pressupostos da teoria neoclássica da firma foi Herbert A. Simon. A obra de Simon alcançou de modo influente campos diversos como Economia, Administração, Psicologia e a Computação. A sua teoria comportamental desdobra-se em dois temas - a racionalidade e a organização -, que, no entanto, não devem ser observados separadamente (Barros, 2004). 
Para Simon, o pressuposto de racionalidade adotado pela economia neoclássica é irreal e dificulta a compreensão dos fenômenos econômicos. Em sua crítica, o autor dirige-se ao pressuposto neoclássico de onisciência dos indivíduos quando diante da necessidade de tomar decisões econômicas (Simon, 1979). Na opiniáo de Simon, o conhecimento perfeito não é possível, e, portanto, também não é possível conhecer todas as alternativas. Desta maneira, também não é possível decidir pela alternativa ótima. A partir daí, ele propõe, então, o conceito de racionalidade restrita ou limitada, de forma que, na tomada de decisóes econômicas, o comportamento possível dos administradores seja o de buscar padróes apenas satisfatórios (e não ótimos, como no pressuposto neoclássico). $\mathrm{Na}$ busca desses padrões, os gestores são levados a projetar suas organizações em relação ao futuro (Simon, 1978).

Ao analisar as ideias de Simon, Barros assinala que a racionalidade restrita ou limitada faz com que o comportamento humano seja dependente do contexto, posto que é nesse que as escolhas são feitas. Nessa linha de raciocínio, a organizaçáo seria o contexto predominante do comportamento econômico. Barros aponta também que, para Simon, as organizaçôes são vinculadas a sistemas abertos nos quais as inovaçóes não resultam da escolha feita de acordo com opçóes conhecidas ou determinadas. Ao contrário, as inovações resultam também das iniciativas das organizaçóes na resolução de problemas (errando e acertando), e aí emerge a importância das decisóes de natureza estratégica por novos produtos, formas de produção, distribuição, etc. Assim, de alguma forma, a organização termina por competir, não somente por mercados já existentes, mas também na criação de outros mercados (Barros, 2004).

Chandler e Simon são autores contemporâneos entre si, e suas formulaçóes têm alguns aspectos em comum: a crítica aos pressupostos neoclássicos da teoria $\mathrm{da}$ firma como ponto de partida. Suas abordagens revelam a limitaçáo e a falta de acuidade da escola neoclássica no tratamento de temas econômicos como a inovação tecnológica ou mesmo a diferenciação entre elas nos mercados, por exemplo.

Em outro aspecto em comum, os dois autores têm seus trabalhos na confluência da Economia e da Administração. Em ambos, é possível identificar a importância do conceito de estratégia quando iluminaram um debate conceitual que, longe de se esgotar, abriu caminho para o aprofundamento de outras questóes. A aproximação da estratégia - tema de natureza mais administrativa - ao raciocínio 
econômico levou diretamente à discussão das mudanças organizacionais.

O exame da literatura leva a concluir que a organização se define por sua estratégia e que os conhecimentos objetivados na produção também se relacionam com sua capacidade de aprender para tornar-se ou manter-se competitiva. Ou seja, a inovação e a mudança organizacional dependem dessa capacidade.

Com tantas palavras associadas à noção de movimento - inovação, mudança e aprendizado -, fica claro que a perspectiva da firma em evoluçấo e em busca de competitividade está presente em Chandler e Simon. Para Nelson, essa busca vincula-se às aptidóes essenciais da organizaçấo, entre as mais importantes às voltadas à inovaçáo. Evidentemente, a noção de aptidóes essenciais de Nelson é muito próxima da noção de competências organizacionais. Esta, por sua vez, sendo um termo bastante disseminado, será tratada adiante.

\section{4_As competências necessárias para competir}

O papel central ocupado pela inovação no contexto da Economia Baseada no Conhecimento leva à constatação de que as competências organizacionais serão mais ou menos desenvolvidas em função do quanto as organizaçôes são capazes de aprender.
Do discutido anteriormente, considera-se que as organizaçóes são diversas entre si, uma vez que, por não dominarem todos os conhecimentos necessários e/ou disponíveis, desenvolvem estratégias e estruturas guiadas na busca por competitividade, vale dizer, por mais conhecimento e aprendizado.

A capacidade de aprender das organizaçóes, por seu turno, está relacionada ao grau de adesão ou de atrelamento da organização a algum(ns) nó(s) das redes de conhecimento existentes na economia que são voltadas para a inovação. Da mesma forma, a aprendizagem vincula-se à adoção e ao desenvolvimento pelas próprias organizaçóes de práticas de aprendizagem geradoras de conhecimentos.

Neste tópico aborda-se o desenvolvimento, a incorporação e o uso das competências pelas organizaçóes, segundo alguns autores. Neste item são tratadas as origens teóricas e o contexto do debate sobre a noçáo de competências organizacionais.

\section{1_Competências: origens do conceito e a visão organizacional}

A origem econômica da noção de competências organizacionais está no interior da abordagem da firma baseada em recursos que, por sua vez, se aninha na microeconomia. O livro clássico da te- 
oria da firma baseada em recursos é The theory of the growth of the firm, editado em 1959 por Edith Penrose. Nesse livro, a autora desenvolve uma linha de análise em que procura aproximar a teoria microeconômica do que ela chama de "organizações de carne e osso". Ela se afasta das definiçóes tradicionais da economia neoclássica que qualificam a firma como mera unidade administrativa. Para a autora, a firma é uma coleçấo de recursos produtivos que podem ser dispostos entre diversos usos e, a qualquer momento, determinados por uma decisáo administrativa. Entre os recursos disponíveis na firma, estão os físicos (constituídos de bens tangíveis como plantas, terra e recursos naturais, estoques náo vendidos de bens finais, etc.) e humanos (trabalho qualificado ou não, staffs administrativo, financeiro, legal, técnico e gerencial) (Penrose, 1980, p. 24).

Penrose conceitua diferentemente recursos e serviços. Os recursos da firma são compostos do conjunto de serviços que podem ser definidos independentemente de seu uso ou não. Os serviços constituem-se na forma como o recurso será usado no âmbito da firma. Na firma, um mesmo recurso pode ser utilizado de diversas maneiras, em diversas combinações e com propósitos diferentes. Como cada firma usa seus recursos de maneira diversa, a distinção entre recurso e serviço torna-se a fonte do caráter único que cada firma assume (Penrose, 1980, p. 24-25).

A autora estuda o crescimento da firma e conclui que, no interior das grandes corporaçóes, a gestấo é caracterizada pela atuação de um time de gerentes, e não pela atuação individual de um único deles. O gerenciamento da empresa torna-se decisivo entre as principais condicionantes de seu crescimento. A composição da equipe de gestáo e seu método de trabalho surgem como fundamentais para o bom desempenho da organização. As capacidades, as experiências e o entrosamento passam a ser qualidades valorizadas dentro da equipe de gestáo e adquiridas com o tempo de trabalho conjunto. Com isso, não se pode melhorar o desempenho de gestáo simplesmente contratando mais gente para trabalhar. Os recém-contratados à empresa podem chegar com boa especialização e qualificação, mas precisarão ganhar experiência trabalhando juntos antes de contribuir eficientemente com as decisóes da empresa (Slater, 1980, p. xi).

A organização seria, então, uma fonte de recursos diversos dotada de uma história, uma trajetória, um conjunto de recursos herdados (acumulados), relaçóes internas (formais e informais) próprias e 
de competências. As competências, nesse contexto, seriam definidas como a capacitação tecnológica e comercial das organizações. Em última análise, suas habilidades únicas e traço distintivo da empresa. Essas competências são seu eixo de coordenação no processo de crescimento, síntese dos conhecimentos e experiências acumulados na organização e fonte de vantagens competitivas consistentes. O modo pelo qual a empresa é administrada em suas diversas atividades é também a particular forma pela qual as competências geram suas vantagens competitivas (capacidade de obter serviços dos recursos) (Souza, 2004).

\section{2_ 0 contexto do debate sobre competências}

A apreensão do conceito de competência só é possível quando sua discussão se vincula à evolução histórica do mundo da produção (Fleury; Fleury, 2000, p. 19). O debate a respeito do uso do conceito de competências no campo dos estudos organizacionais iniciou-se na década de 1970 com a participação de pesquisadores dos EUA e da Europa. Nesse debate questionou-se intensamente o modelo taylorista-fordista de organizaçáo do trabalho. As primeiras posições procuravam identificar os conhecimentos, as habilidades e as atitudes do trabalhador como suas competências. De maneira simples, tais abordagens ainda se mantinham vinculadas aos conceitos tradicionais dos requisitos necessários para a ocupação de um cargo.

Uma análise importante desse conceito é desenvolvida por Zarifian (2001). Esse autor francês examina as características históricas do trabalho industrial e identifica três mudanças ocorridas no final do século XX que interferem no trabalho na empresa contemporânea:

a_ Passa a prevalecer a noção de evento. $\mathrm{O}$ evento seria aquilo que perturba o funcionamento normal da máquina produtiva de maneira parcialmente inesperada de modo a ir além da capacidade de autorregulaçáo da própria máquina. $\mathrm{O}$ evento pode acontecer nos ambientes interno e externo da organização (Zarifian, 2001, p. 41-42).

b_ Intensificação e dependência da comunicação. Este fato consiste no

"[...] entendimento recíproco e bases de compromissos que serão garantia do sucesso das açōes desenvolvidas em conjunto" (Zarifian, 2001, p. 45).

c_Predomínio do serviço. Passa a vigorar a noção de que trabalhar 
é gerar serviço. Assim, o serviço seria

"[...] uma modificação no estado ou nas condiçóes de atividade de outro ser humano, ou de uma instituição, que chamaremos de destinatários do serviço (o cliente, o usuário ou o setor público)" (Zarifian, 2001, p. 48).

Essas três características implicariam importantes mudanças no funcionamento das organizaçóes. Os eventos imprevistos tornam-se cada vez mais freqüentes (mas ainda imprevistos em seu conteúdo e consequências). Com isso, as exigências em relação aos trabalhadores e organizaçôes ultrapassam as atividades a eles anteriormente prescritas. Assim, trabalhar significa ir além dos limites descritos para tarefas de cada cargo, e torna-se

"[...] o prolongamento da competência que o individuo mobiliza em face de uma situação profissional cada vez mais mutável e complexa" (Fleury; Fleury, 2000, p. 20).

Zarifian constata que, no padrão taylorista-fordista, a forte pressão pela divisão do trabalho diminui a importância da comunicação na produção. Na percepção do autor, na atualidade, o desempenho das organizaçóes vincula-se fortemente à qualidade das interaçóes. Em outras palavras, o desempenho das organizaçóes liga-se às comunicaçóes que ocorrem dentro delas por meio de seus indivíduos. A noçáo de serviço envolve o atendimento ao cliente interno ou externo à organização e, por ser central, logo está em todas as atividades. Por extensão, a comunicação torna-se fundamental na realização dos serviços (Fleury; Fleury, 2000, p. 20).

$\mathrm{Na}$ comunicação estabelecem-se os processos de troca de informaçóes e aprendizado necessários à solução dos problemas surgidos a partir dos eventos, assim como os acordos sobre os objetivos organizacionais. As relaçóes entre evento, comunicação e aprendizado integram-se, portanto, ao aprendizado organizacional.

$\mathrm{O}$ efeito combinado da presença dos conceitos de evento, serviços e comunicação nas organizaçóes conduziria ao surgimento de um "modelo da competência" ou de uma "lógica da competência” (Zarifian, 2001, p. 134). A competência seria definida segundo três elementos complementares como:

"[...] a tomada de iniciativa e responsabilidade do indivíduo em situaçôes profissionais com as quais ele se defronta [...]"; "...] uma inteligência prática das situaçôes, que se apóia em conhecimentos adquiridos e os transforma ̀̀ medida que a diversidade das situaçôes aumenta [...]"; "[...] a faculdade de 
mobilizar redes de atores em volta das mesmas situaçôes, de compartilhar desafios, de assumir áreas de responsabilidade” (Zarifian, 2001, p. 68, 72, 74).

$\mathrm{O}$ autor explica o surgimento desse modelo ou a lógica e, dada a definição de competências do indivíduo, apresenta os seus desdobramentos práticos, ou seja, as competências organizacionais deles decorrentes.

Os aspectos vinculados à questão das competências e sua gestão abrem uma agenda extensa de discussóes. Entre elas, as formas de organização do trabalho e de remuneração a elas associadas, e a formação e educação do trabalhador segundo as novas exigências do mundo do trabalho. Especialmente neste último aspecto, a contribuição de Zarifian é importante por estabelecer ligaçóes entre o debate sobre competências do âmbito estritamente privado das organizaçóes e as políticas públicas voltadas para a formação do trabalhador. ${ }^{9}$

Fleury analisa a posição de Zarifian sobre competências e conclui pela necessidade de um desenho de modelo que relacione as competências individuais dos trabalhadores às competências organizacionais, buscando compor um todo coerente nas formas de ação em termos estratégicos na organização.
$\mathrm{Na}$ dimensão da organização, o alinhamento entre estratégias e as competências organizacionais pode ser identificado em duas abordagens: a da firma baseada em recursos e a perspectiva da estratégia competitiva (Fleury, 2000, p. 44). Segundo a perspectiva da firma baseada em recursos - dado o potencial de recursos tangíveis e intangíveis existentes no interior da organização -, as suas escolhas estratégicas não deveriam se definir apenas em função das oportunidades oferecidas pelo mercado. A observação dos recursos internos da organização e a posterior definição das vantagens competitivas da organização conformam uma estratégia de "dentro para fora" (Fleury; Fleury, 2000, p. 44).

Hamel e Prahalad (1995) seguem essa estratégia quando criam o conceito de competências essenciais -

\section{"[...] um conjunto de habilidades e tec- nologias que permite a uma empresa oferecer um determinado beneficio aos clientes" (Hamel; Prahalad, 1995, p. 229).}

As competências essenciais têm, segundo esses autores, três características: permitem a diversificação da presença da empresa em diversos mercados, criam efetivamente valor para os clientes e, por fim, são difíceis de ser copiadas pela concorrência (Mintzberg et al., 2000). A gestão da organização

\footnotetext{
${ }^{9}$ No Brasil, a exemplo do verificado na Itália, na Espanha e na França, a discussão de políticas públicas voltadas para a formação dos trabalhadores tem contado com a participaçáo de sindicatos. Como exemplo, houve nos governos de Fernando Henrique Cardoso (1995-2002) o Plano Nacional de Formação (Planfor), financiado com recursos do Fundo de Amparo ao Trabalhador (FAT). Entretanto, o debate sobre a relação entre competências e políticas públicas não será aprofundado neste trabalho por não constar de seus objetivos.
} 
empenhar-se-ia no desenvolvimento e na aplicação dessas competências em uma abordagem contida na visão da firma baseada em recursos de Penrose, uma vez que, conforme essa autora, é do uso dos recursos tangíveis e humanos da organização que se originam as competências essenciais. $\mathrm{O}$ conceito de competências essenciais é peça importante no posicionamento da organização diante da concorrência, e, por isso, seu enraizamento na gestão é necessário. Os gestores devem encarregar-se de cinco tarefas ao lidar com as competências da organizaçáo:

"(1) identificar as competências essenciais existentes; (2) definir uma agenda de aquisição de competências essenciais; (3) desenvolver as competências essenciais; (4) distribuir as competências essenciais, e (5) proteger e defender a liderança das competências essenciais" (Hamel; Prahalad, 1995, p. 261).

A estratégia competitiva tem como precedente teórico importante a visão de Schumpeter sobre a competição capitalista. Em Schumpeter, a competição é um processo em que as empresas ganhadoras esforçam-se pela inovaçáo de produtos, processos ou tecnologias, que, na sua chegada vitoriosa ao mercado, destroem as antigas referências nele existentes. A capacidade de aprender mais e mais rapidamente para ocupar o mercado com o novo permite que a organização acumule conhecimento e, assim, introduza assimetrias de informação como vantagens em relação à concorrência (Araújo Jr., 1999, p. 4).

Segundo Fleury, esse tipo de estratégia exige da empresa compreensão do setor, ramo ou indústria em termos de suas características e tendências. Uma vez identificado o nicho de mercado privilegiado em que a empresa pode se posicionar, são tomadas as decisóes gerenciais necessárias para a sua mobilização em direção a esse objetivo. Essa abordagem estratégica poderia ser chamada como "de fora para dentro", posto que o posicionamento da empresa é definido após o estudo sobre seu mercado (Fleury; Fleury, 2000, p. 44). A organização nesse caso seria bem-sucedida quando fosse capaz de oferecer ao seu cliente o menor custo de um produto em relação à concorrência, ou então de oferecer produtos cujos "benefícios singulares" mais que compensassem custos mais elevados (Porter, 1992, p. 2).

Fleury assinala que, na prática, as empresas combinam as duas visóes (firma baseada em recursos e vantagem competitiva) em busca da melhor escolha em termos das competências organizacionais. As atuais características de funcionamen- 
to da economia - intensa competição, forte ritmo de inovaçóes, entre outras exigem acima de tudo uma visão estratégica que se preocupe tanto com a dinâmica do mercado quanto com a própria organização e suas possibilidades. A definição das competências da organização é elemento-chave dentro da estratégia.

Fleury liga mais objetivamente as escolhas estratégicas da organização e suas competências organizacionais. Em primeiro lugar, o referencial para as competências é dado segundo a estratégia adotada pela organização. Em segundo lugar, acrescentam-se a essa orientação estratégica os tipos de competência pelas quais a organização pretende se destacar no mercado. Fleury aponta que as classificaçóes são modelos ideais para efeito de análise. Por meio das várias combinaçóes possíveis entre eles, porém, é possível identificar e escolher estrategicamente as formas de atuação da organização de acordo com suas competências, de modo que haja alinhamento entre as competências organizacionais e individuais.

Também dentro da abordagem da firma baseada em recursos, Mills et al. estabelecem uma distinção entre recursos e competências. Os recursos são a base a partir da qual as competências da organização se manifestam, e essas são avaliadas segundo o desempenho obtido perante os concorrentes nos aspectos reconhecidos pelos clientes (Mills et al., 2002). A abordagem de Mills et al. é bastante semelhante à enunciada por Penrose, quando esta diferencia recursos e serviços (forma como o recurso será usado na organização). Tais autores pretendem dar mais operacionalidade ao conceito de competências organizacionais no que se refere às práticas de gestão. Para isso, qualificam mais objetivamente alguns serviços da firma (no conceito de Penrose) como competências tendo em vista diversas modalidades. Para Mills et al., as competências organizacionais podem ser definidas segundo: sua centralidade na empresa (as essenciais), a percepção do cliente em termos de diferenciação relativamente à concorrência (distintivas), sua localização na estrutura da empresa (de unidade de negócio) e o posicionamento na estrutura de competências da organização (competência de suporte ou metacompetência). Além dessas, há a capacidade dinâmica - competência organizacional que viabiliza permanentemente a adaptação das demais competências da organização.

$\mathrm{O}$ quadro a seguir apresenta sinteticamente a visão dos autores consultados a respeito do conceito, características e tipos de competência organizacional. 


\section{Quadro 2_Competências organizacionais}

\begin{tabular}{|c|c|}
\hline $\begin{array}{l}\text { Hamel e } \\
\text { Prahalad } \\
(1995)\end{array}$ & $\begin{array}{l}\text { - Competências essenciais: são capazes de viabilizar vantagens reais ao cliente, permitir o acesso a diversos } \\
\text { mercados e ser de difícil imitação pelos concorrentes. O principal aspecto relativo às competências essenciais é } \\
\text { a capacidade de articulação dos recursos da organização. }\end{array}$ \\
\hline $\begin{array}{l}\text { Teece e Pisano } \\
(1994)\end{array}$ & $\begin{array}{l}\text { - Capacidades dinâmicas: permitem a firma gerar novos produtos e processos em resposta às mudanças } \\
\text { do mercado. As capacidaded dinâmicas referem-se especialmente à forma como a organização, usando } \\
\text { recursos internos e externos, desenvolve e renova suas competências internas. Estas capacidades dependem, } \\
\text { intensamente do trabalho dos gestores. }\end{array}$ \\
\hline $\begin{array}{l}\text { Mills et al. } \\
(2002)\end{array}$ & $\begin{array}{l}\text { Tipos de competência: } \\
\text { - Competências essenciais: usualmente se referem às atividades de alta competência mais no nível corporativo da } \\
\text { firma e são a chave para a sobrevivência da firma e centrais para sua estratégia. } \\
\text { - Competências distintivas: referem-se às atividades de alta competência que os clientes reconhecem como } \\
\text { diferenciadoras de sua firma em relação aos seus competidores, sendo, portanto, uma vantagem competitiva. } \\
\text { - Competência organizacional ou competência de unidade de negócio: pequeno número de atividades-chave } \\
\text { (duas a seis), esperadas de cada unidade de negócio na organização. } \\
\text { - Competências-suporte ou metacompetências: } \\
\text { atividade que é valorizada por ser o suporte de uma gama de outras. } \\
\text { - Capacidade dinâmica: capacidade da firma para adaptar suas competências o tempo todo. Estreitamente } \\
\text { relacionada com os recursos importantes para as mudanças. }\end{array}$ \\
\hline $\begin{array}{l}\text { Fleury; Fleury } \\
(2000)\end{array}$ & $\begin{array}{l}\text { Definição: um saber agir responsável e reconhecido, que implica mobilizar, integrar, transferir conhecimentos, } \\
\text { recursos, habilidades, que agreguem valor econômico à organização e valor social ao indivíduo. } \\
\text { - Tipos de estratégia (relacionadas às competências): excelência operacional, inovação no produto, } \\
\text { orientada para serviço. } \\
\text { - Tipos de competência (envolvendo organizaçáo e seus indivíduos): organizacional, social e técnica. }\end{array}$ \\
\hline
\end{tabular}

Fontes: Fleury; Fleury (2000), Hamel e Prahalad (1995), Mills et al. (2002), Zarifian (2001). 
Os conceitos enunciados por Mills et al. encontram similaridade naqueles apontados por Hamel e Prahalad no que se refere à centralidade das competências essenciais para as organizaçóes. Contudo, enquanto para Hamel e Prahalad o reconhecimento pelos clientes é uma das características das competências essenciais, para Mills et al. o reconhecimento ou a percepção do cliente, em termos do valor proporcionado por uma competência, justifica a definição de um tipo específico de competência, a distintiva.

Tanto no caso de Hamel e Prahalad quanto no de Mills et al., um ponto importante passa a ser: como tornar uma competência percebida (Hamel e Prahalad) ou distintiva (Mills et al., 2002). A resposta pode ser encontrada em dois pontos. Em primeiro lugar, é preciso que a organização tenha ou desenvolva um recurso que, uma vez utilizado, alcance a percepção do cliente. Em segundo lugar, o destaque ou desenvolvimento dessa competência organizacional, vale dizer, sua mobilização, dependerá de uma competência específica da organização, que em Mills et al. (2002). é a chamada capacidade dinâmica da organização. Essa competência diz respeito à capacidade de a organização adaptar constantemente as suas competências, e a partir dali torná-las perceptíveis ao cliente.
Teece e Pisano são os principais autores no que se refere ao conceito de capacidades dinâmicas. Sua abordagem também se filia à firma baseada em recursos de Penrose, que reconhece a relevância das capacidades específicas de cada firma. Teece e Pisano chamam a atenção para um subconjunto de competências da organização, e as nomeiam capacidades dinâmicas, ou seja, que permitem o desenvolvimento e a renovação de suas competências.

No foco desses autores, essas capacidades permitem a criação e a disseminação de novos conhecimentos na organização, conformando as habilidades da organização em aprender, adaptar-se e mudar, renovando-se todo o tempo. $\mathrm{O}$ ponto central dessa abordagem seria que, diante da incessante mudança no ambiente, o sucesso na competição relacionar-se-ia à habilidade das organizaçóes em reconfigurar seus recursos organizacionais internos e externos da melhor forma. Tal habilidade dependeria, por sua vez, do trabalho desenvolvido por seus gestores (Boerner et al., 2001, p. 109-110).

A discussão em torno do conceito de competências e seu conjunto variado de autores e respectivas posiçóes sinaliza a sua importância para a definição das estratégias e dos processos nas organizaçóes. Para a organização, não basta ter competências, é preciso ter "a” competência de mudar/ 
inovar e, assim, manter-se na competição. Ocorre que, para mudar e se reconfigurar, a organização depende essencialmente de aprender como fazer isso. Trata-se de, organizacionalmente, aprender para mudar e como mudar. A compreensão sobre como o aprendizado organizacional ocorre e a criação das melhores condiçóes para que isso aconteça é objeto de estudos de inúmeros pesquisadores, como veremos no próximo tópico.

\section{5_A aprendizagem organizacional e seus elementos}

$\mathrm{Na}$ economia do aprendizado, mudar e aprender são verbos que integram um processo circular e cumulativo voltado à competição, à inovação e novamente à competição, e assim por diante. $\mathrm{O}$ ritmo ditado pelas mudanças e pela avidez do mercado por inovações obriga as organizações a estabelecer estratégias que, por sua vez, só se viabilizam com a identificação e o uso de seus recursos e competências. As mudanças ou não das competências das organizações relacionam-se à transformação da organização (em suas estruturas e processos, p. e.) e de seu ambiente externo.

Os processos de aprendizagem organizacional combinam a leitura do ambiente de atuação da empresa, dos seus recursos internos e das possibilidades oferecidas pe- las redes constituídas no(s) sistema(s) dos quais a organizaçáo toma parte. $\mathrm{Na}$ parte seguinte, são apresentados um histórico a respeito das origens do debate da aprendizagem organizacional e as questóes mais atuais relativas ao tema.

\section{1_Breve histórico da teoria}

O debate sobre aprendizagem organizacional inaugurou-se com os primeiros artigos na década de 1960, mas, somente no final dos anos 70, uma série mais regular de estudos e publicaçóes começou a ser divulgada. Entre os trabalhos mais significativos desse período, estão os de Argyris e Schön (1978), Duncan e Weiss (1979) e March e Olsen (1975). Nas décadas de 80 e 90, o volume de trabalhos publicados internacionalmente cresceu de maneira expressiva, transformando o tema em um dos principais entre os estudos organizacionais (Prange, 2001, p. 42).

Os conceitos de aprendizagem de ciclos simples e duplo e as teorias de ação esposada e em uso de Argyris e Schön (1978) são referências comuns nos trabalhos desse período. Outra presença constante nos trabalhos da área é a espiral de conhecimento e os modos de transferência de Nonaka e Takeuchi (1997). Peter Senge, que ajudou a popularizar a expressão organizaçóes de aprendizagem, ou seja, a organização permanentemente 
orientada em suas estruturas e processos para o aprendizado, é outro autor bastante referenciado ${ }^{10}$ (Senge, 1990).

A inserção da aprendizagem como tema da organização precisa levar em consideração o complexo contexto de interações sociais, como apontam a Filosofia, a Sociologia, a Psicologia e a Pedagogia e suas várias possibilidades de abordagem. Com tais fundamentos, esse é um assunto cuja delimitação conceitual não é simples. Neste item apontaremos a evolução epistemológica da questão (destacando a variedade de abordagens possíveis e as tentativas de classificação como forma de clarear o campo). Os principais assuntos da aprendizagem organizacional são, entâo, destacados com o objetivo de conectá-los à discussão econômica.

\section{2_0 debate sobre aprendizagem organizacional}

Há grande variedade de perspectivas sobre a aprendizagem organizacional no campo dos estudos organizacionais. A opção deste estudo é a de aproximação com a aprendizagem organizacional com base na sistematização já realizada por autores de trabalhos expressivos no campo.

Nicolini e Meznar apontam pelo menos duas razóes para a variedade de posiçóes no debate sobre aprendizagem organizacional. A primeira razão reside nas várias características da aprendizagem organizacional. Sob esse fenômeno se abrigariam, por exemplo, quatro tipos de processo: a aquisição de conhecimento, a distribuição e a interpretação de informação e a memória organizacional. A decisão de estudar a aprendizagem envolveria de saída uma escolha de qual das características do fenômeno abordar (Nicolini; Meznar, 1995 citando Huber, 1991).

Uma segunda razão consiste nas diversas maneiras de conceituar aprendizagem organizacional. Citando Shrivastava (1983), esses autores apontam ser possível sintetizar a aprendizagem organizacional de quatro maneiras diferentes: como experiência institucional, como fenômeno de adaptação, como processo de mudança de pressupostos compartilhados e, por fim, como processo de relaçóes resultantes de açôes e conhecimentos desenvolvidos (Nicolini; Meznar, 1995).

A pesquisa sobre a aprendizagem organizacional pode envolver, portanto, priorizaçóes quanto a qual característica do fenômeno estudar e, por outro lado, uma escolha quanto à sua própria definição. Independentemente da sua validade, as simples combinaçóes de possibilidades de abordagens entre as duas razóes apontadas por Nicolini e Meznar já são suficientes como referência da multiplicidade de visóes existentes. (2005, p 14), a expressão "organização de aprendizagem" tem entrado em desuso, prevalecendo a expressão "aprendizagem organizacional” para essa mesma acepção. 
Na expressão de Prange, existe uma "selva de aprendizagem organizacional', que está se tornando cada vez mais densa e impenetrável", residindo aí uma das principais preocupaçóes dos pesquisadores (Prange, 2001, p. 42). Como consequ- ência, é grande o número de estudos que compilam a produção e a pesquisa realizada sobre o tema tentando identificar seus pontos comuns e diversidade de posiçóes entre os autores. $\mathrm{O}$ quadro a seguir sintetiza os principais pontos destacados por

\section{Quadro 3_Aprendizagem organizacional - alguns aspectos destacados da literatura}

\begin{tabular}{|c|c|}
\hline $\begin{array}{l}\text { Fiol e Lyles } \\
(1985)\end{array}$ & $\begin{array}{l}\text { - apontam as áreas de consenso e dissenso dentro do campo; } \\
\text { - distinguem aprendizagem organizacional de adaptação organizacional e mostram que a mudança não } \\
\text { necessariamente implica aprendizado; } \\
\text { - apontam que a aprendizagem pode ser de alto e de baixo nível e que isso pode provocar impactos diferenciados na } \\
\text { gestáo estratégica da firma. }\end{array}$ \\
\hline $\begin{array}{l}\text { Nicolini e } \\
\text { Meznar (1995) }\end{array}$ & $\begin{array}{l}\text { - reveem as diferentes abordagens para aprendizagem organizacional apontando as causas para a diversidade de } \\
\text { perspectivas; } \\
\text { - discorrem sobre a importância do esquecimento ou desaprendizagem organizacional; } \\
\text { - propóem a abordagem de construçáo social e o caráter institucional da aprendizagem organizacional. }\end{array}$ \\
\hline $\begin{array}{l}\text { Easterby-Smith } \\
\text { e Araujo (2001) }\end{array}$ & $\begin{array}{l}\text { - apontam as diferenças entre os conceitos de aprendizagem organizacional e organização de aprendizagem; } \\
\text { - apontam os problemas e as oportunidades da discussão sobre aprendizagem em termos dos trabalhos empíricos, } \\
\text { desenvolvimentos teóricos e utilizaçáo. }\end{array}$ \\
\hline Prange (2001) & $\begin{array}{l}\text { - compara os desenvolvimentos teóricos em aprendizagem organizacional aplicando critérios de consistência, } \\
\text { contribuiçáo descritiva X prescritiva; } \\
\text { - defende o uso de metáforas e analogias no estudo da aprendizagem organizacional. }\end{array}$ \\
\hline Huysman (2001) & $\begin{array}{l}\text { - revisa deficiências da literatura de aprendizagem organizacional destacando quatro tendências (à melhoria, à açáo } \\
\text { individual, à adaptaçáo ambiental, à aprendizagem planejada) e suas respectivas propostas para sua correçáo. }\end{array}$ \\
\hline Elkjaer (2001) & $\begin{array}{l}\text { - vê a existência de duas abordagens diferentes para aprendizagem organizacional e organizaçóes de aprendizagem: } \\
\text { como ferramenta gerencial (cognição individual) e segundo sua ocorrência em ambientes sociais (aprendizagem } \\
\text { situada); } \\
\text { - defende que uma teoria sobre aprendizagem organizacional e organizaçóes de aprendizagem deve ser tomada pela } \\
\text { perspectiva da teoria da aprendizagem social. }\end{array}$ \\
\hline Antonello (2005) & $\begin{array}{l}\text { - revisa a literatura existente e constata a evolução do conceito de aprendizagem organizacional; } \\
\text { - entende que o conceito de mudança permeia todas as visóes sobre aprendizagem organizacional; } \\
\text { - identifica seis focos na abordagem da aprendizagem organizacional: aprendizagem individual e coletiva, cultura, } \\
\text { gerenciamento do conhecimento, melhoria contínua, inovaçáo e sistemas/processos. }\end{array}$ \\
\hline
\end{tabular}

Fontes: Antonello (2005), Elkjaer (2001), Easterby-Smith e Araujo (2001), Fiol e Lyles (1985), Huysman (2001), Nicolini e Meznar (1995) e Prange (2001). 
seis trabalhos sobre a produção teórica de aprendizagem organizacional.

O quadro anterior - também uma compilação - exemplifica o esforço de sistematização que repetidas vezes é realizado pelos pesquisadores com um duplo intuito: organizar as principais ideias do campo e apresentar a própria contribuição.

O trabalho de Fiol e Lyles (1985), o primeiro desse quadro, revisa a literatura e identifica em meio à variedade de posiçóes três pontos de consenso entre os autores sobre aprendizagem organizacional: a relevância do alinhamento, a distinção entre aprendizagem individual e organizacional e a presença de quatro fatores contextuais no processo de aprendizagem (cultura, estratégia, estrutura e ambiente). Analisaremos cada um deles pela sua importância para este estudo.

\section{a_Relevância do alinhamento da organização com 0 ambiente}

Este consenso está centrado na noção de que, para garantir sua sobrevivência de longo prazo e crescimento, a organizaçáo deve alinhar-se por si própria ao ambiente para manter-se competitiva e inovativa. $\mathrm{O}$ alinhamento da organização torna-se peça importante na gestão estratégica, implicando o desenvolvimento de potencial da organização em termos de aprendizagem, desaprendizagem ou mesmo de re- aprendizagem com base em comportamentos passados (Nicolini; Meznar, 1995) e (Fiol; Lyles, 1985, p. 804).

\section{b_Distinção entre aprendizagem individual e organizacional}

O aprendizado individual é importante para a organização, mas a produção de conhecimento organizacional não é simplesmente a soma dos aprendizados individuais. Isso porque a organização é capaz de criar e manter sistemas de aprendizado que não somente atuam sobre seus integrantes, como também são capazes de comunicar suas formas de organização, história e normas a outros. $\mathrm{Ou}$, de outra forma, o aprendizado organizacional é capaz de viabilizar a leitura e a compreensão de seu ambiente e, assim, providenciar as ações para tornar suas estratégias viáveis (Fiol; Lyles, 1985, p. 804).

\section{c Presença de quatro fatores contextuais no processo de aprendizagem: cultura, estratégia, estrutura e ambiente}

Para os autores envolvidos com a aprendizagem organizacional, esses fatores estabelecem com ela uma relação circular, posto que, de uma só vez, eles criam a aprendizagem, são criados por ela e também a reforçam (Fiol; Lyles, 1985, p. 804).

O Quadro 4 mostra que os pontos de consenso identificados ainda possuem 


\section{Quadro 4_Aprendizagem organizacional - consensos e questões em aberto}

\begin{tabular}{|c|c|}
\hline Consensos & Questões em aberto \\
\hline $\begin{array}{l}\text { Alinhamento da } \\
\text { organização com o } \\
\text { ambiente }\end{array}$ & $\begin{array}{l}\text { - críticas quanto a uma excessiva ênfase dada à força da abordagem da } \\
\text { gestáo estratégica em relação ao ambiente; } \\
\text { - crítica quanto a uma dicotomia patente entre a organização e o ambiente. }\end{array}$ \\
\hline $\begin{array}{l}\text { Aprendizagem } \\
\text { individual e } \\
\text { organizacional }\end{array}$ & $\begin{array}{l}\text { - não há definição clara sobre a relação entre a aprendizagem individual } \\
\text { e a organizacional. }\end{array}$ \\
\hline Fatores contextuais & $\begin{array}{l}\text { - Cultura: postura cognitiva organizacional, formada por ideologias } \\
\text { internas e padróes de comportamento, ou como estilos estratégico e } \\
\text { cognitivo; } \\
\text { - Estratégia: estratégia produz stress, que provoca adaptação e } \\
\text { aprendizagem. Por outro lado, a definição de objetivos estratégicos } \\
\text { também é dependente da capacidade de aprendizagem da organização. } \\
\text { Os processos de formulação e implementação estratégica são } \\
\text { estimuladores de aquisição de conhecimento; } \\
\text { - Estrutura: alguns autores veem a estrutura como resultado da } \\
\text { aprendizagem organizacional. Outros entendem que as diferentes } \\
\text { estruturas têm impacto sobre a aprendizagem. Nessa segunda linha, } \\
\text { há disputas para identificar qual estrutura é mais conducente à } \\
\text { aprendizagem; } \\
\text { Ambiente: aqui discussóes já abordadas no ponto consensual sobre o } \\
\text { alinhamento da organização relativamente ao ambiente são retomadas. } \\
\text { Além disso, há discussões sobre a relação entre a complexidade } \\
\text { ambiental e a capacidade de aprendizagem da organização (grande } \\
\text { complexidade prejudica aprendizagem por sobrecarga de exigência, e } \\
\text { baixa complexidade também prejudica a capacidade de aprendizagem } \\
\text { por produzir sonolência organizacional). }\end{array}$ \\
\hline
\end{tabular}
Fonte: Nicolini e Meznar (1995) e Fiol e Lyles (1985).

dentro de si grande conjunto de questóes em aberto.

No que se refere ao alinhamento da organização ao seu ambiente, as po- lêmicas subjacentes remetem a questóes como a de validade da teoria contingencial: na relação entre ambiente e organização, o que determina o que e em que proporçăo? 
Outra questão vincula-se ao tipo de aprendizado que se estabelece na relação entre indivíduos (organizaçóes ou não) e ambiente.

Já com relação à existência de aprendizagem individual e organizacional, podem ser identificadas pelos menos duas posiçóes. Na primeira, considera-se que os agentes da ação e aprendizagem organizacional são os membros individuais da organização (Argyris; Schön, 1978; Klein, 1989 in Nicolini; Meznar, 1995). Na segunda, afirma-se a importância de tomar a organização e sua estrutura como agentes do processo (Cyert; March, 1963; Duncan; Weiss, 1979; Levitt; March,1988; Lant; Mezias, 1990; in Nicolini; Meznar, 1995). Entre um extremo e outro, há ainda a percepção de que a aprendizagem pode acontecer no nível intermediário dos coletivos ou grupos intraorganizacionais. (Huber, 1991 in Prange, 2001, p. 47) e (Crossan et al., 1999).

Por fim, quanto aos fatores contextuais, cada um deles integra um campo de estudo próprio nas organizaçóes. Desta maneira, toda a gama de debates em torno de conceitos e políticas associados à cultura, à estratégia, à estrutura e ao ambiente acrescenta-se à discussão sobre aprendizagem.

Há inúmeras polêmicas subjacentes a cada um dos pontos de consenso sobre a aprendizagem organizacional. Fiol e Lyles buscam, no entanto, com base nesses, cla- rear o campo de discussão, aproximando as posiçóes existentes em termos de conteúdo e níveis de aprendizado. Segundo as autoras, a mudança, a adaptação e o aprendizado nas organizaçóes - com presença consistente na literatura - sempre foram assuntos relacionados à forma como as organizaçôes ajustam-se a seu ambiente. A seguir, apontaremos como as autoras diferenciam o que são a mudança e a adaptação (Fiol; Lyles, 1985, p. 805).

Segundo as autoras, a mudança relacionar-se-ia aos ajustes provocados na organização em suas maneiras de interpretar os eventos e como se desenvolvem a compreensão e os esquemas explicativos entre seus membros. A mudança haveria de se referir, assim, a um desenvolvimento cognitivo da organização, sendo essa uma atitude consciente. A adaptação, por sua vez, consistiria no surgimento de açóes e respostas da organização na forma de novos comportamentos, não necessariamente conscientes. Dessa maneira, para melhor definição sobre o que se origina no ajuste entre a organização e o seu ambiente em termos de conteúdo, é preciso identificar se houve alteração comportamental ou cognitiva (Fiol; Lyles, 1985, p. 806). A interpretação, ou seja, a atitude consciente de compreensáo dos eventos como elemento importante da aprendizagem organizacional receberá maior atenção deste trabalho. 
A preocupação das autoras é diferenciar esses dois processos mostrando ser possível ocorrer ajustes no comportamento da organização, sem que tenha ocorrido nenhum desenvolvimento cognitivo. Da mesma forma, pode haver desenvolvimento cognitivo na organização, sem que nela ocorra alteraçáo de comportamento. Na opinião das autoras, haveria o aprendizado da organização por meio do desenvolvimento cognitivo (Fiol; Lyles, 1985, p. 806).

Essas posições sobre mudança ou adaptação da organização em relação ao ambiente se estabelecem na perspectiva de que é possível demarcar onde termina um fato no ambiente e onde se constata a aprendizagem no indivíduo - em nosso caso, a organização - a partir de uma atitude consciente ou alteração de seu comportamento. Em outras palavras, trata-se de separar o indivíduo e seu objeto quando do aprendizado.

Analisando como acontece o conhecimento, Maturana e Varela afirmam que a demarcação entre indivíduo e objeto não é uma questáo relevante para a aprendizagem. Eles entendem que indivíduos e objetos interagem compondo uma cena em que os dois sofrem modificaçóes em um processo de natureza circular. Assim, conforme os autores, "todo fazer é um conhecer e todo conhecer é um fazer" (Maturana; Varela, 2001, p. 32). Valendo-se desses autores, as organizaçôes são consideradas sujeitos da aprendizagem em um processo cuja circularidade diminui a importância de se saber se o fenômeno estudado foi de adaptação ao ambiente ou de adaptação do ambiente à organização.

A concordância com Maturana e Varela torna importante identificar sinais de que alguma aprendizagem ocorreu. Destaca-se, então, o papel da memória organizacional. Segundo Levitt e March, a memória consistiria no conhecimento obtido baseando-se na experiência da organização (Levitt; March, citado em Sims, 2001, p. 65-66). Diante de um desenvolvimento cognitivo importante na organização, essa memória pode ser alterada nos seus aspectos tangíveis (registros e regras formais escritas) ou intangíveis (fruto das diversas interpretaçóes possíveis dentro da organização, seus grupos e indivíduos).

As alteraçóes da memória organizacional significam a existência de aprendizado que, por sua vez, exige a verificação da extensão em que isso aconteceu. Em outras palavras, torna-se necessária uma métrica para o aprendizado organizacional. Fiol e Lyles atentam para a extensão do desenvolvimento cognitivo, bem como para o nível em que se realizou. O aprendizado de baixo nível fica ca- 
racterizado como o que ocorre segundo fenômenos simples e repetitivos e dentro $\mathrm{da}$ estrutura e das regras organizacionais. Seus efeitos são normalmente de curto prazo e apenas parciais sobre a organização e seus membros. Já no aprendizado de alto nível, é possível ocorrer mudanças nas regras, bem como o aperfeiçoamento no comportamento da organização diante de seus problemas. $\mathrm{O}$ aprendizado de alto nível é, portanto, mais complexo, sendo capaz de reconhecer relaçóes de causa e efeito nos fenômenos enfrentados pela organização e por seus membros.

A abordagem de Fiol e Lyles ilumina dois aspectos importantes para este trabalho no que se refere à aprendizagem organizacional: a definição do foco de sua atenção nos aspectos cognitivos da organização e também dos níveis em que ela acontece. Essa abordagem também acomoda teoricamente contribuiçóes importantes como as de Argyris e Schön (1978) - aprendizagem de ciclos simples e duplo - também baseadas em pressupostos cognitivistas.

Segundo tais autores, a aprendizagem de ciclo simples envolveria a detecção e a solução de problemas de acordo com as regras estabelecidas pela organização (sua teoria de ação). Essa detecção, no entanto, envolve as contradiçóes entre a teoria de ação esposada pelos indivídu- os e a teoria em uso, ou seja, aquela realmente colocada em prática por eles. Os autores apontam que os indivíduos afirmam seguir uma teoria e, na verdade, inconscientemente praticam outra. Dessa contradição emerge um comportamento defensivo em relação à detecção de erros e/ou problemas e sua consequente correção. Em outras palavras, surge uma resistência a observar de maneira crítica as situaçóes, inibindo o questionamento das regras e dos procedimentos existentes e a chegada às soluçóes. A aprendizagem de ciclo duplo envolveria a superaçáo dessa postura defensiva, o questionamento do estabelecido na organização e, por meio do aprendizado da situação, a promoção das mudanças necessárias para a concretização das soluções (Argyris, 2000).

Do apresentado até aqui a respeito da aprendizagem organizacional, fica a percepção da sua associação à noção de movimento e fluxo. Adaptação, alinhamento, ajustes, desenvolvimento cognitivo e interaçáa são palavras que pressupóem a existência de um movimento dos indivíduos e das organizações de uma determinada posição em termos de conhecimento para outra posição. Antonello também coteja as diversas abordagens existentes para esse debate. Em sua síntese para tais abordagens, a noção de movimento traduz-se na presença da 
mudança nas organizaçóes e, associada a esta, da aprendizagem.

Conforme Antonello, a "[...] literatura existente promove uma relação forte entre aprender e mudar" (Antonello, 2005, p. 18). A pressão pela mudança seria ocasionada pelo ambiente concorrencial instável no qual as organizaçóes estão imersas. Nesse ambiente, a capacidade de sobrevivência das organizaçóes associa-se diretamente à sua capacidade de mudar a si própria. A autora identifica na literatura seis diferentes focos de exigências de aprendizado organizacional, todos eles permeados pela noção de mudança. ${ }^{11}$ A relação aprendizagem-mudança é tratada de diversas maneiras pelos autores. Em Argyris e Schön, a preocupação é sobre o que barra o aprendizado e a consequente mudança nas organizaçóes. Em outros autores, o objetivo é a criação de condições adequadas na organização para a mudança, ou mesmo classificação da mudança oriunda do aprendizado, entre outros. Antonello aponta que, de maneira geral, o conceito de aprendizagem organizacional tem como qualidade seu caráter "dinâmico e agregador" em relação à discussão da teoria da mudança (Antonello, 2005, p. 17). A despeito disso, a diversidade de abordagens para a aprendizagem organizacional é objeto de grande debate.

\section{6_De volta à Economia e concluindo}

$\mathrm{O}$ fenômeno da aprendizagem organizacional, se compreendido e de alguma forma gerido ou facilitado, resulta na criação de outras competências nas organizações, tornando-as mais competitivas. $\mathrm{O}$ aprendizado das organizaçóes resulta em muito da relação que elas estabelecem com seus contextos externo e interno, tanto em termos de influência recebida quanto exercida, sendo, portanto, relevantes suas escolhas em termos de estratégia e estrutura.

Em verdade, na raiz da Economia Baseada no Conhecimento, também existe uma economia do aprendizado que, para tanto, exige ao menos a identificação de seus elementos no nível organizacional.

Em termos mais gerais, este trabalho toma como pertinente o conceito de Prange sobre a aprendizagem organizacional como lente para o estudo das mudanças ocorridas nas organizaçóes. Sob essa lente, a aprendizagem organizacional pode ser definida como:

Um processo de construção social que responde a eventos internos e externos na organização, criando novas interpretaçóes da realidade que são armazenadas na memória organizacional quando devidamente institucionalizadas. Seus produtos - interpretaçóes e

\footnotetext{
e Gestáo de Conhecimento (Antonello, 2005, p. 17).

${ }^{11}$ Aprendizagem Individual e Coletiva, Melhorias e Gestão de Qualidade Total, Sistema e Processos, Inovação, Cultura
} 
mudanças concretas da realidade - têm diferentes niveis de complexidade e profundidade na organização. (Prange, 2001)

Os elementos constituintes dessa definição permitem que a conexão da aprendizagem organizacional com a Economia se sustente. Assim, dos eventos (externos ou internos) à organização, surgem as perturbaçóes que a levam a aprender (e criar outras interpretaçóes da realidade) e mudar. Tais aprendizados e mudanças, por sua vez, podem ter diferentes níveis de complexidade para a organização. Em poucas palavras, com base no que acontece nos ambientes internos e externos das organizaçóes, há a criação de outros produtos, incorporação de tecnologias, adoção ou desenvolvimento de inovações organizacionais, e assim por diante.

Como destacado em Chandler e Simon, sem o pressuposto de onisciência ou de conhecimento perfeito de parte das organizaçóes, o caminho que resta é o da relação com seu contexto externo e interno valendo-se de decisóes por estratégias, estruturas e práticas que lhe permitam o acesso à competitividade pela via do aprendizado.

A fim de abrigar a importância econômica da aprendizagem organizacional, Matthews desenvolve o conceito de aprendizagem econômica para analisar os níveis em que o aprendizado pode acontecer dentro de uma economia, tomando as firmas e seu ambiente como referências. Por meio desse conceito, verifica-se o quanto algumas economias nacionais são mais hábeis do que outras em acomodar mudanças provocadas por novos produtos, tecnologias ou mesmo pelo surgimento de mercados (Matthews, 1996, p. 161).

No quadro seguinte, observa-se como Matthews estabelece níveis de aprendizado dentro da Economia. Para o autor, o aprendizado econômico guarda paralelo com a aprendizagem organizacional, quando esta estabelece níveis dentro dos quais o aprendizado pode acontecer no interior das firmas. ${ }^{12}$

Dentro da Economia, as instituiçôes de alguma forma ligadas ao polo mais dinâmico do mercado - ou seja, aquele em que o conhecimento é cada vez mais intensivo como insumo produtivo - tornam-se (ou deveriam tornar-se) organizaçóes de aprendizagem (OECD, 1996, p. 14). Atentas às possibilidades de aprendizado nos três níveis enunciados por Matthews dentro da Economia, as organizaçóes devem garantir a contínua preparação de sua gestão, habilidades e estrutura para o novo.

O campo teórico da aprendizagem organizacional continua em construção tanto por conta do andamento da espe-

\footnotetext{
${ }^{12}$ Argyris e Schön tratam os níveis de aprendizagem organizacional conforme sua extensão e profundidade (Argyris e Schön (1978).
} 


\section{Quadro 5_Aprendizagem econômica - níveis e descrição}

\begin{tabular}{ll} 
Níveis & $\begin{array}{l}\text { Descrição } \\
\text { Primeira ordem }\end{array}$ \\
\hline Segunda ordem & $\begin{array}{l}\text { Acontece no interior das firmas por meios dos próprios } \\
\text { esforços de aprendizado; }\end{array}$ \\
\hline clusters de colaboração de firmas;
\end{tabular}

Fonte: Matthews (1996, p. 161).

${ }^{13}$ Ver Sveiby (1998),

Garvin (2000) e Stewart

(2002), por exemplo. culação conceitual quanto da pesquisa nas organizaçóes. Cabe notar, entretanto, que a importância do tema para o desempenho e o posicionamento estratégico das organizações não concede tempo suficiente para que o debate conceitual ou a pesquisa amadureçam e ofereçam resultados definitivos para aplicação por parte dos gestores. Por conta disso, autores não exatamente acadêmicos - consultores e administradores profissionais - também tomam parte desse debate.

Em geral, o viés desses autores é bastante prescritivo, propondo modelos e ferramentas gerenciais voltadas para a gestão da aprendizagem, normalmente baseados na sua experiência profissional. ${ }^{13}$ Com essa orientação, seus trabalhos voltam-se fortemente para a ação, valorizando a gestão nos seus aspectos de diagnósticos e avaliação de processos e produtos (Easterby-Smith; Araujo, 2001). Esses autores agregam à discussão sobre aprendizagem organizacional aspectos interessantes das próprias experiências, mas eles tendem "[...] a carecer de objetividade crítica, própria do trabalho acadêmico tradicional" (Easterby-Smith; Araujo, 2001, p. 16). Este trabalho privilegiou abordagens de perfil mais acadêmico, mas não deixa de notar a existência de um forte mercado sobre e para a aprendizagem organizacional.

De qualquer forma, o tratamento do conhecimento e da aprendizagem organizacional torna-se cada vez mais frequente na Economia e na Gestão. No nível das organizaçôes propriamente dito, os exemplos vão das ferramentas e práticas de gestão de conhecimento e seus desdobramentos na forma de sistemas corporativos até as iniciativas cada vez mais estruturadas de educação corporativa.

A experiência e a pesquisa na área de educação corporativa, por exemplo, demonstram que a consistência econômica das decisões organizacionais tomadas depende em muito do seu vínculo efetivo com as diretrizes estratégicas (Eboli, 2010).

No nível sistêmico, a conexão das organizaçóes às universidades, aos centros de pesquisa e aos órgãos de financiamento e a conformação de redes de conhecimento 
e de um sistema nacional de inovação também envolvem aprendizagem organizacional, como referido em Matthews.

Espera-se que este trabalho tenha contribuído para mostrar que a aprendizagem organizacional - produto e/ou processo nas organizações - é determinante de suas mudanças no ambiente competitivo. Em resumo, ao aprender, a organização pode criar outras competências que lhe permitam inovar, mudar e permanecer no mercado segundo sua estratégia. 


\section{Referências bibliográficas}

ANTONELlO, Claudia S. A metamorfose da aprendizagem organizacional. In: RUAS, R.; ANTONELLO, C. S.; BOFF, L. H. (Org.). Os novos horizontes da gestão: aprendizagem organizacional e competências. Porto Alegre: Bookman, 2005.

ARAÚJO JR., José T.

Schumpeterian competition and its policy implications: The Latin American Case. Revista de Economia Política, São Paulo, v. 19, n. 4 (76), out./dez. 1999.

ARGYRIS, C. Ensinando pessoas inteligentes a aprender. In: Gestão do Conhecimento. Rio de Janeiro: HBR, Campus, 2000.

ARGYRIS, Chris; SCHÖN, Donald A. Organisational learning: a theory of action perspective. Massachussets: Addison-Wesley, 1978.

BARROS, G. Racionalidade e organizaçōes: Um estudo sobre o comportamento econômico na obra de Herbert A. Simon. Dissertação (Mestrado em Economia) - FEA, Universidade de São Paulo, São Paulo, 2004
BOERNER, Christopher S.; MATCHER, Jeffrey T.; TEECE, David J. A review and assessment of organizational learning in economic theories. In: DIERKES, Meinolf et al. Handbook of organizational learning \& knowledge. Oxford: Oxford Universtity Press, 2001.

CHANDLER, A. D. Strategy and structure. Chapters in the History of the Industrial Enterprise. Cambridge, Mass.: MIT Press, 1962. CROSSAN, Mary M.; LANE, Henry W.; WHITE, Roderick E. An organizational learning framework: From intuiton to institution. In: Academy of Management, The Academy Management Review, vol. 24, n. 3, p. 522-537, July 1999.

CYERT, R.; MARCH, J.

A behavioral theory of the firm. Englewood Cliffs, NJ: PrenticeHall, 1963.

DUNCAN, R.; WEISS, A.

Organizational learning: implications for organisational design. In: STAW, B. M.; CUMMINGS, L. L. (Ed.) Research in organisational behavior. Greenwich, C.T: JAI Press, 1979.
EASTERBY-SMITH, Mark; ARAUJO, Luis. Aprendizagem organizacional: Oportunidades e debates atuais. In: Aprendizagem organizacional e organizaçôes de aprendizagem - desenvolvimento na teoria e na prática. São Paulo: Atlas, 2001.

EASTERBY-SMITH, Mark; LYLES, Marjorie (Orgs.). The Blackwell handbook of organizational learning and knowledge management. Oxford: Blackwell, 2003.

EBOLI, Marisa. Educação corporativa no Brasil: Mitos e verdades. São Paulo: Gente, 2004.

EBOLI, Marisa. Fundamentos e evolução da educação corporativa. In: EBOLI, M.; FISCHER, A. F.; MORAES, F. C. C.; AMORIM, W. A.C. Educaçäo corporativa: Fundamentos, evoluçấo e implantaçấo de projetos. São Paulo: Atlas, 2010

ELKJAER, Bente. Em busca de uma teoria de aprendizagem social. In: Aprendizagem organizacional e organizaçōes de aprendizagem - Desenvolvimento na teoria e na prática. São Paulo: Atlas, 2001.
FIOL, M.; LYLES, M.

Organizational learning.

Academy of Management

Review (pre-1986); Oct. 1985.

FLEURY, Afonso; FLEURY, Maria

T. L. Estratégias empresariais e formação de competências: Um quebra-cabeça caleidoscópico da indústria brasileira. São Paulo: Atlas, 2000.

FONSECA, Eduardo G. O capital humano na Filosofia Social de Marshall. Revista de Economia Política, São Paulo, v. 12, n. 12 (46), abr./jun. 1992.

FORAY, D.; LUNDVALL, B.

From Economics of knowledge to the learning economy. In: Employement and growth in the knowledge-based economy. Paris: OECD, 1996.

FUSFELD, D. A era do economista. São Paulo: Saraiva, 2001.

GARVIN, D. Construção da organização que aprende. In: Gestão do Conhecimento. Rio de Janeiro: HBR, Campus, 2000.

HAMEL, Gary; PRAHALAD, C. K. Competindo pelo futuro: Estratégias inovadoras para obter o controle do seu setor e criar os mercados de amanhá. Rio de Janeiro: Campus, 1995. 
HUBER, G. P. Organizational learning: The contributing processes and the literature. Organization Science, v. 2, n. 2, p. $88-115,1991$

HUYSMAN, M

Contrabalançando tendenciosidades: Uma revisão crítica da literatura sobre aprendizagem organizacional. In: Aprendizagem organizacional e organizaçốes de aprendizagem Desenvolvimento na teoria e na prática. São Paulo: Atlas, 2001.

KLEIN, J. Parenthetic learning in organizations: Toward the unlearning of unlearning model. Journal of Management Studies, n. 26, p. 291-308, 1989

KNIGHT, K. A descriptive model of the intra-firm innovation process. Journal of Innovation Management, p. 479-496, Oct. 1967

LANT, T.; MEZIAS, S.

Managing discontinuous change: a simulation study of organizational learning and entrepreneurship. Strategic Management Journal, n. 11, p. $147-179,1990$

LENHARI, L. C.; QUADROS, R.

Recursos humanos nas economias baseadas no conhecimento. Revista Inteligência Empresarial, Rio de Janeiro, n. 12, jul. 2002.

LEVITT, B.; MARCH, J. Organizational learning. Annual Review of Sociology, n. 14, p. $319-340,1988$
LUNDVAll, B. Políticas de innovación en la economía de aprendizaje. Revista Latinoamericana de Estudios del Trabajo, ańo 8, n. 16, 2003. Associación Latinoamericana de Sociología. Buenos Aires.

MACHLUP, F. The production and distribution of knowledge in the United States. Princeton University Press, Princeton, NJ, 1962.

MARCH, J. G.; OLSEN, J. P. The uncertainty of the past: Organisational learning under ambiguity. In: MARCH, J. G.

Decisions and organisations.

Oxford: Blackwell, 1975.

MARShALl, Alfred. Principios de Economia. São Paulo:

Nova Cultura, 1985.

MATTHEWS, John.

Organizational foundations of the knowledge-based economy. In: Employement and growth in the knowledge-based economy. Paris: OECD, 1996.

MATURANA, H. R.; VARELA, Francisco J. A árvore do conhecimento: As bases biológicas para a compreensão humana. São Paulo: Palas Athena, 2001.

MEISTER, Jeanne C. Educação corporativa. São Paulo: Pearson Makron Books, 1999.

MIGLIOLI, Jorge. Acumulação de capital e demanda efetiva. São Paulo: Editora T. A.

Queiroz, 1985.
MILLS, John; PLATTS, Ken; BOURNE, Michael; RICHARDS, Hull. Strategy and performanceCompeting trough competences. Cambridge University Press, Cambridge, 2002.

MINTZBERG, Henry; AHLSTRAND, Bruce; LAMPEL, Joseph. Safári de estratégia: Um roteiro pela selva do planejamento estratégico. Porto Alegre: Bookman, 2000.

MOREIRA, Daniel A.; QUEIROZ, Ana C. Inovação organizacional e tecnológica. São Paulo: Thomson Learning, 2007.

NELSON, R. R. As fontes do crescimento econômico. Campinas: Editora da Unicamp, 2006.

NICOLINI, D.; MEZNAR, M

B. The social construction of organisational learning: conceptual and practical issues. Human Relations, v. 48, n. 7, 1995.

NONAKA, Ikujiro; TAKEUCHI, Hirotaka. Criação do conhecimento: Como as empresas japonesas geram a dinâmica da inovação. Rio de Janeiro: Campus, 1997.

OECD, Organisation for Economic Co-Operation and Development. The knowledgebased economy. OCDE/CG (96) 102. Paris, 1996. Disponível em: <http://www.oecd.org/ dataoecd/51/8/1913021.pdf>. Acesso em: 01/06/2004
PAULA, João A.; CERQUEIRA, Hugo E. G.; ALBUQUERQUE, Eduardo M. Trabalho e conhecimento: Liçóes de clássicos para a análise do capitalismo contemporâneo. In: Estudos Econômicos. São Paulo: FIPE-USP, v. 30, n. 3, p. 419-445, jul./set. 2000.

PENROSE, E. The theory of the growth of the firm. Oxford: Basil Blackwell, 1980.

PORTER, M. E. Vantagem competitiva: Criando e sustentando um desempenho superior. Rio de Janeiro: Campus, 1992

PRANGE, C. Aprendizagem organizacional -

desesperadamente em busca de teorias? In: Aprendizagem organizacional e organizaçóes de aprendizagem - Desenvolvimento na teoria e na prática. São Paulo: Atlas, 2001.

SCHUMPETER, J. A. Capitalismo, socialismo e democracia. São Paulo: Zahar Editores, 1984.

SCHUMPETER, J. A. A teoria do desenvolvimento econômico. São Paulo: Abril Cultural, 1982.

SENGE, Peter. A quinta disciplina. Sáo Paulo: Best Seller, 1990.

SHRIVASTAVA, P. A tipology of organizational learning system. Journal of Management Studies, Oxford, v. 20, n. 1, p. 7, 28, 1983.

SIMON, H. A. Rationality as process and as product of thought. American Economic Review, v. 68, n. 2, p. 1-16, 1978. 
SIMON, H. A. Rational decision making in business organizations. American Economic Review, v. 69, n. 4, p. 493-513, 1979.

SIMS, David. Aprendizagem organizacional como desenvolvimento de histórias: Cânones, apócrifos e mitos piedosos. In: Aprendizagem organizacional e organizaçōes de aprendizagem - Desenvolvimento na teoria e na prática. São Paulo: Atlas, 2001.

SLATER, Martin. Foreword. In: PENROSE, E. The theory of the growth of the firm. Oxford: Basil Blackwell, 1980.

SOUZA, Maria C. A. F. Bases conceituais da gestão do conhecimento. Apresentação em power point. Grupo de Estudos e Trabalho sobre Gestáo do Conhecimento GeTGC-PUC, 2004.

STAL, Eva; CAMPANÁRIO, Milton de Abreu; ANDREASSI, Tales; SBRAGIA, Roberto (coord.); SANTOS, Abílio (coord. geral do tema central). Inovaçâo: Como vencer esse desafio empresarial. São Paulo:

Clio Editora, 2006.

STEWART, Thomas A. A riqueza do conhecimento: $\mathrm{O}$ capital intelectual e a organização do século XXI. Rio de Janeiro: Campus, 2002.

SVEIBY, Karl E. A nova riqueza das organizaçôes: Gerenciando e avaliando patrimônios de conhecimento. Rio de Janeiro: Campus, 1998.
TEECE, David T.; PISANO, G.

The dynamic capabilities of firms: An introduction. Industrial and corporate change, v. 1, n. 3, 1994.

\section{ZARIFIAN, P. Objetivo}

competência: Por uma nova lógica. São Paulo: Atlas, 2001

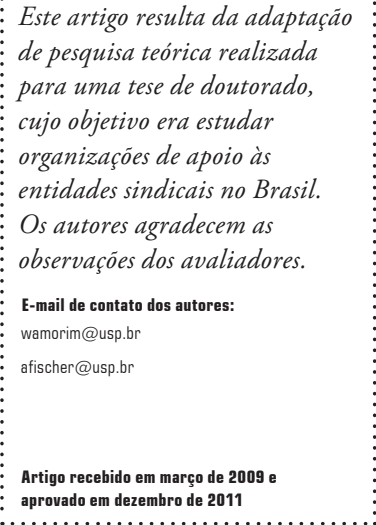

